\title{
Comparison of aerosol and bioaerosol collection on air filters
}

\author{
Ewa Miaskiewicz-Peska • Maria Lebkowska
}

Received: 25 October 2010/Accepted: 2 September 2011/Published online: 17 September 2011

(C) The Author(s) 2011. This article is published with open access at Springerlink.com

\begin{abstract}
Air filters efficiency is usually determined by non-biological test aerosols, such as potassium chloride particles, Arizona dust or di-ethyl-hexylsebacate (DEHS) oily liquid. This research was undertaken to asses, if application of non-biological aerosols reflects air filters capacity to collect particles of biological origin. The collection efficiency for nonbiological aerosol was tested with the PALAS set and ISO Fine Test Dust. Flow rate during the filtration process was $720 \mathrm{l} / \mathrm{h}$, and particles size ranged $0.246-17.165 \mu \mathrm{m}$. The upstream and downstream concentration of the aerosol was measured with a laser particle counter PCS-2010. Tested bioaerosol contained 4 bacterial strains of different shape and size: Micrococcus luteus, Micrococcus varians, Pseudomonas putida and Bacillus subtilis. Number of the biological particles was estimated with a culture-based method. Results obtained with bioaerosol did not confirmed $100 \%$ filters efficiency noted for the mineral test dust of the same aerodynamic diameter. Maximum efficiency tested with bacterial cells was $99.8 \%$. Additionally, cells reemission from filters into air was also studied. Bioaerosol contained 3 bacterial strains: Micrococcus varians, Pseudomonas putida and Bacillus subtilis. It was proved that the highest
\end{abstract}

E. Miaskiewicz-Peska $(\bowtie) \cdot$ M. Lebkowska Department of Biology, Faculty of Environmental Engineering, Warsaw University of Technology, 20 Nowowiejska St., 00-653 Warsaw, Poland e-mail: ewa.miaskiewicz@is.pw.edu.pl intensity of the reemission process was during the first 5 min. and reached maximum $0.63 \%$ of total number of bacteria retained in filters. Spherical cells adhered stronger to the filter fibres than cylindrical ones. It was concluded that non-biological aerosol containing particles of the same shape and surface characteristics (like DEHS spherical particles) can not give representative results for all particles present in the filtered air.

Keywords Aerosol - Bioaerosol - Air filtration · Reemission

\section{Introduction}

Filtration is a method applied worldwide in air treatment. The most common air filters are made of woven material. To test its efficiency in particles collection, American Standard ASHRAE 52.2 (1999) recommends potassium chloride $(\mathrm{KCl})$ aerosol while European Standard EN 779 (2002)—di-ethyl-hexylsebacate (DEHS) liquid oily particles of spherical shape and smooth surface. Nevertheless, airborne particles may be of different shapes and surface structure, for example particles of biological origin such as pollen, bacterial cells, endospores, fungal cells, spores and filaments. Moreover, they may be present in the air as aggregates-pairs, chains or clusters (Wake et al. 1995, Gorny et al. 1999). Very common airborne 
bacteria $M$. luteus occurs in 8-cell cubic packets, staphylococci form irregular clusters, and Penicillium melinii spores are often released into air in short chains. The fraction of airborne particles of biological origin may amounts up to $37 \%$. It is estimated that the average number of bacteria and fungi suspended in the air reaches $1.2 \times 10^{4}$ cells $/ \mathrm{m}^{3}$ and $7.3 \times 10^{2}$ spores $/ \mathrm{m}^{3}$, respectively (Heikkinen et al. 2005). According to Martikainen et al. (1990) and Martiny et al. (1994), the number of microbial cells deposited in the air filters reaches $10^{3}$ to $10^{5} \mathrm{cfu} / \mathrm{g} / \mathrm{cm}^{2}$ (Maus et al. 2001). Charkowska (2000) listed fungal strains isolated from air filters among which there are such genera as Aspergillus, Penicillium, Cladosporium, Phoma and Mucor and also bacteria Pseudomonas spp. Ahlen et al. (1999) isolated thermotolerant microorganisms (mainly Aspergillus fumigatus and A. niger) from air filters installed in HVAC systems located in different areas in Norway. Trunov et al. (2001) found out that surface properties and agglomeration of bioaerosol particles have an influence on filters collection efficiency. This study shows that biological particles give different characteristics of filters efficiency than mineral test dust.

\section{Materials and methods}

Filtration materials were two woven air filters $\mathrm{P} 2$ and P3 (Secura B.C., Warsaw, Poland). They were hydrophobic and made of polypropylene. The diameter of P2 fibres was $6.7 \pm 2.0 \mu \mathrm{m}$ and P3 filter $4.4 \pm 1.0 \mu \mathrm{m}$. The efficiency of the P2 and P3 filters corresponded to High Efficient Particulate Air Filters (HEPA) H11 and H13 class, respectively (PNEN1822-1 2010).

The experimental set-up used in the test with mineral aerosol was a PALAS set (PALAS GmbH, Karlsruhe, Germany). It comprised of the following units: aerosol generator RGB1000, laser particle counter PCS-2010, PCS-PUMPE compressor, electrical charge equilibrator CD-2000 and a control panel of MFC-CONTROL system. The experiments were conducted with mineral aerosol ISO Fine Test Dust, model 12103-1-A2 (Powder Technology Incorporated, USA). The upstream aerosol mass concentration equalled $75 \mathrm{mg} / \mathrm{m}^{3}$; particles size ranged from 0.246 to $17.165 \mu \mathrm{m}$. The flow rate during the filtration process was maintained at $720 \mathrm{l} / \mathrm{h}$. (1) air filter, (2) pressure reducer, (3) rotameter, (4) air flow regulator, (5) Collison nebulizer, (6) filtration column, (7) air filters tested.

The experimental set-up applied in the research work with biological aerosol is presented in Fig. 1. It was used to filter bioaerosol and thus test filters efficiency. In the second part of the experimental work, the set-up was applied to study the release of bacterial cells from the air filters. The main element was a filtration column (6) where air filters (7) were placed. Compressed air was pre-filtered (1) and divided into two streams. One of them passed through a pressure reducer R110-A00 (CONTROLMATICA ZAP-PNEFAL Ltd., Poland) (2) and rotameter (3), and the second one through an air flow regulator FC261 (Mykrolis Corp., USA) (4), to a bioaerosol generator-a 1-jet Collison nebulizer (Grimm Aerosol Technik GmbH \& Co., Airing, Germany) (5). Air flow rate was adjusted at $360 \mathrm{l} / \mathrm{h}$. Aerosolized biological particles, together with the air stream, which passed through the anemometer, entered a filtration column (6). The column had two outlets that enabled sampling before and after air filtration. Microorganisms entered a Collison nebulizer as a suspension in sterile water with a flow rate $30 \mathrm{ml} / \mathrm{h}$. It was dosed via a syringe pump (Motor Infumat Driver, MTA KUTESZ, Hungary). The stream of the liquid and the air met at a right angle. Bioaerosol was dried in a cylindrical vessel, diluted and finally dosed to a filtration column. The air filter efficiency was measured at the flow rate 600 and $800 \mathrm{l} / \mathrm{h}$ with the mixed bioaerosol and, additionally, at 200 and $400 \mathrm{l} / \mathrm{h}$, with $M$. luteus.

The following bacterial strains, of different cell morphology, were selected as test organisms: Micrococcus luteus, Micrococcus varians, Pseudomonas putida and Bacillus subtilis. Micrococcus luteus form spherical cells with diameter of 1.0-2.0 $\mu \mathrm{m}$. They are mostly found in cubical 8-cell packets. $M$. varians has spherical cells, $1.0-1.5 \mu \mathrm{m}$ in diameter observed mostly singly but also in pairs and irregular clusters. $P$. putida cells are Gram-negative rods of $0.7-1.1 \mu \mathrm{m}$ by $2.0-4.0 \mu \mathrm{m}$, and B. subtilis form rods (Gram positive) of $0.7-0.8 \mu \mathrm{m}$ by $2.0-3.0 \mu \mathrm{m}$. The two types of rods are present mostly singly.

The number of bacterial cells in the filtration column was estimated by a culture-based method. Bioaerosol was sampled by the Krzysztofik slit bioaerosol impactor (Krzysztofik 1992) at a fixed flow rate $1,200 \mathrm{l} / \mathrm{h}$. Plates, placed in the impactor, 
Fig. 1 Experimental set-up for filtration efficiency experiments and reemission studies

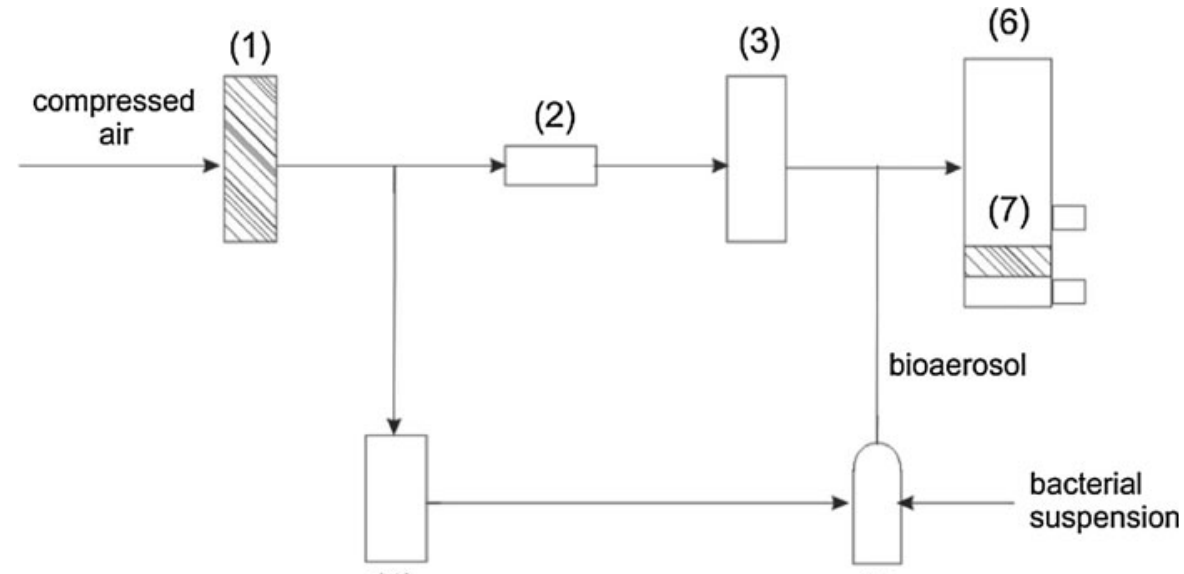

(4)
(5) contained Plate Count Agar medium (Merck, Germany) to support bacterial growth. Plates were incubated in $26^{\circ} \mathrm{C}$ for $48 \mathrm{~h}$. Morphology of bacterial colonies was characteristic for each bacterial strain, which allowed to differentiate and count them.

Filtration efficiency $(\eta)$ was calculated according to the Eq. 1:

$\eta=\frac{X-Y}{X} 100 \%$

where $X$ - the average number of bacteria upstream of the filters $\left(\mathrm{CFU} / \mathrm{m}^{3}\right)$ and $Y$ - the average number of bacteria downstream of the filters.

$X=\frac{\sum_{i=1}^{n} X_{i}}{n}$,

where $X_{i}$-the number of bacteria for each replicate $\left(\mathrm{CFU} / \mathrm{m}^{3}\right)$ and $n$-number of replicates.

$X_{i}=\frac{a_{i}}{V t}$

where $a_{i}$-number of colonies on a plate, $V$-air flow rate $\left(\mathrm{m}^{3} / \mathrm{h}\right)$ and $t$-sampling time $(\mathrm{h})$.

$Y=\frac{\sum_{i=1}^{n} Y_{i}}{n}$,

where $Y_{i}$ represents the number of bacteria for each replicate $\left(\mathrm{CFU} / \mathrm{m}^{3}\right)$ and $n-$ number of replicates.

$Y_{i}=\frac{a_{i}}{V t}$

where $a$-number of colonies on a plate, $V$-air flow rate $\left(\mathrm{m}^{3} / \mathrm{h}\right)$ and $t$-sampling time $(\mathrm{h})$.
The phenomenon of bacterial cells reemission from filters into air was also studied. The experimental setup presented in Fig. 1 was used in the series of experiments. A test bioaerosol consisted of three bacterial strains: Micrococcus varians, Pseudomonas putida and Bacillus subtilis. Bioaerosol was applied on filters P2 during $15 \mathrm{~min}$. at the flow rate $400 \mathrm{l} / \mathrm{h}$. After that, filters were turned upside down and the air passed with the flow rate $800 \mathrm{l} / \mathrm{h}$ within $20 \mathrm{~min}$. The bioaerosol downstream of the filters was sampled within $20 \mathrm{~min}$. The same experiment was carried out at the air flow $600 \mathrm{l} / \mathrm{h}$, but samples were collected every $5 \mathrm{~min}$. within $25 \mathrm{~min}$. Air flow rate in the slit aerosol impactor was $1,200 \mathrm{l} / \mathrm{h}$ and sampling time $5 \mathrm{~min}$. Bacteria were cultivated on the Plate Count Agar medium (Merck, Germany) at $26^{\circ} \mathrm{C}$ for $48 \mathrm{~h}$. The concentration of bacteria in the air $\left(N_{\mathrm{a}}\right)$ was expressed as $\mathrm{CFU} / \mathrm{m}^{3}$ (colony forming units per $\mathrm{m}^{3}$ of the air).

The number of bacteria remaining on the filter, $N_{\mathrm{f}}$ (after the reemission was finished), was also estimated. Every tested filter was placed in $100 \mathrm{ml}$ of $0.08 \%$ sterile sodium pyrophosphate solution with the addition of $0.0005 \%$ polyoxyethylenesorbitan monooleate (Tween 80) in a glass flask. The flask with the filter sample was agitated in a water bath shaker (Elpan water bath shaker type 357 , Poland) for $40 \mathrm{~min}$. to detach bacterial cells from the filter fibres. The number of bacteria was determined by the plate count method-serially diluted samples were plated onto Petri dishes (0.1 ml each) filled with Plate Count Agar (Merck, Germany). After incubation for $48 \mathrm{~h}$ in $26^{\circ} \mathrm{C}$, characteristic bacterial colonies were counted. The 
concentration of bacteria was expressed as CFU/ $21.2 \mathrm{~cm}^{2}$ (colony forming units per surface of the filter from which bacterial cells were emitted).

Reemission rate $(R)$ was determined as follows:

$R=\frac{N_{\mathrm{a}}}{N_{\mathrm{a}}+N_{\mathrm{f}}} 100 \%$

The experiments were done in triplicate. The differences between the results obtained were evaluated and expressed as standard deviation.

\section{Results and discussion}

In the experiment with mineral aerosol, P2 and P3 filters were characterized by a very high fractional efficiency. Particles of the diameter $\leq 1.1 \mu \mathrm{m}$ were retained in $99.83(\mathrm{P} 2)$ and $99.90 \%(\mathrm{P} 3)$. The highest efficiency, $100 \%$, for non-biological aerosol was noticed for particles of the diameter $>1.1 \mu \mathrm{m}$.

In the experiment with bioaerosol, the filtration efficiency was never as high as $100 \%$ (Tables 1,2 ). In case of the three bacterial strains used as a test bioaerosol in the filtration experiment, efficiency of the process was very high and exceeded $99 \%$ with average value $99.7 \%$. Differences between the results for bacterial strains were insignificant-99.8\% for $B$. subtilis and $99.5 \%$ for M. varians (Table 2).

P2 and, additionally, P3 filters were also tested with bioaerosol containing only one bacterial strain $-M$. luteus. In this experiment, the air flow was adjusted at 200, 400, 600 and $800 \mathrm{l} / \mathrm{h}$. Changes in filtration efficiency are presented in Fig. 2. It was noticed that filtration efficiency for P2 decreased from 97.8 (200 l/ h) to $96.5 \%(800 \mathrm{l} / \mathrm{h})$; for P3 it dropped from 98.4 to $95.9 \%$.
Filters capacity to collect bacterial cells tended to decrease as a result of the air flow rate increases. The most significant fall was observed within the range $400 \mathrm{l} / \mathrm{h}-600 \mathrm{l} / \mathrm{h}$.

Filtration efficiency for $M$. luteus bioaerosol occurred $0.3-4 \%$ lower than for mixed bioaerosol: M. varians, $P$. putida and B. subtilis at the air flow 600 and 800 l/h (Fig. 3).

Aerodynamic diameters, $d_{\mathrm{a}}$ estimated for aerosolized bacterial cells, were as follows: $B$. subtilis $1.14 \mu \mathrm{m}$, P. putida $1.5 \mu \mathrm{m}$, M. varians $1.75 \mu \mathrm{m}$ and M. luteus $2.8 \mu \mathrm{m}$. It was found in this study that $\mathrm{P} 2$ and P3 filters collection efficiency reached $100 \%$ for nonbiological particles in the size range $1.14-2.8 \mu \mathrm{m}$, while bacterial cells were never retained so effectively (Fig. 3).

The lowest filtration efficiency-96.5\%-was observed in case of M. luteus packets, while bacterial cells of the three other strains were retained by filters with very similar and high effectiveness $99.5-99.9 \%$. The phenomenon can be explained by the surface characteristics of $M$. luteus cubic cells' packets, which can be regarded as spiny particles. As a consequence, these 8-cell packets hardly attached to the fibres of filtering material and were unable to penetrate the filtering medium. Smooth particles-cells of the other bacterial test strains-developed stronger contact with filters and, despite their smaller size, were retained with higher efficiency. It suggests that not only the particle size but also the particle shape is important in standard aerosol selection. Particles of non-biological test aerosols are, preferably, of spherical shapes, like DEHS particles recommended by EN 779 (2002). Obviously, it is not representative for all particles of biological origin, for example fungal spores and bacterial cells, as described earlier by Jankowska et al. (2000).

Table 1 Results of the air filtration efficiency experiment, flow rate 600 1/h

\begin{tabular}{|c|c|c|c|c|c|}
\hline \multirow[t]{2}{*}{ Bacteria } & \multicolumn{2}{|l|}{ Upstream } & \multicolumn{2}{|l|}{ Downstream } & \multirow{2}{*}{$\begin{array}{l}\text { Filtration } \\
\text { efficiency (\%) }\end{array}$} \\
\hline & $\begin{array}{l}\text { Number of } \\
\text { bacteria }\left(\mathrm{CFU} / \mathrm{m}^{3}\right)\end{array}$ & $\begin{array}{l}\text { Standard } \\
\text { deviation }\end{array}$ & $\begin{array}{l}\text { Number of } \\
\text { bacteria }\left(\mathrm{CFU} / \mathrm{m}^{3}\right)\end{array}$ & $\begin{array}{l}\text { Standard } \\
\text { deviation }\end{array}$ & \\
\hline Micrococcus varians & 13,000 & 3,600 & 290 & 35 & 99.8 \\
\hline Bacillus subtilis & 190,000 & 20,000 & 510 & 53 & 99.7 \\
\hline Pseudomonas putida & 140,000 & 56,000 & 91 & 85 & 99.9 \\
\hline Total & 343,000 & 59,000 & 891 & 67 & 99.7 \\
\hline
\end{tabular}


Table 2 Results of the air filtration efficiency experiment, flow rate $800 \mathrm{l} / \mathrm{h}$

\begin{tabular}{|c|c|c|c|c|c|}
\hline \multirow[t]{2}{*}{ Bacteria } & \multicolumn{2}{|l|}{ Upstream } & \multicolumn{2}{|l|}{ Downstream } & \multirow{2}{*}{$\begin{array}{l}\text { Filtration } \\
\text { efficiency }(\%)\end{array}$} \\
\hline & $\begin{array}{l}\text { Number of } \\
\text { bacteria }\left(\mathrm{CFU} / \mathrm{m}^{3}\right)\end{array}$ & $\begin{array}{l}\text { Standard } \\
\text { deviation }\end{array}$ & $\begin{array}{l}\text { Number of } \\
\text { bacteria }\left(\mathrm{CFU} / \mathrm{m}^{3}\right)\end{array}$ & $\begin{array}{l}\text { Standard } \\
\text { deviation }\end{array}$ & \\
\hline Micrococcus varians & 420,000 & 110,000 & 2,000 & 900 & 99.5 \\
\hline Bacillus subtilis & 950,000 & 180,000 & 1,700 & 460 & 99.8 \\
\hline Pseudomonas putida & 510,000 & 300,000 & 1,900 & 860 & 99.6 \\
\hline Total & $1,880,000$ & 580,000 & 5,600 & 850 & 99.7 \\
\hline
\end{tabular}

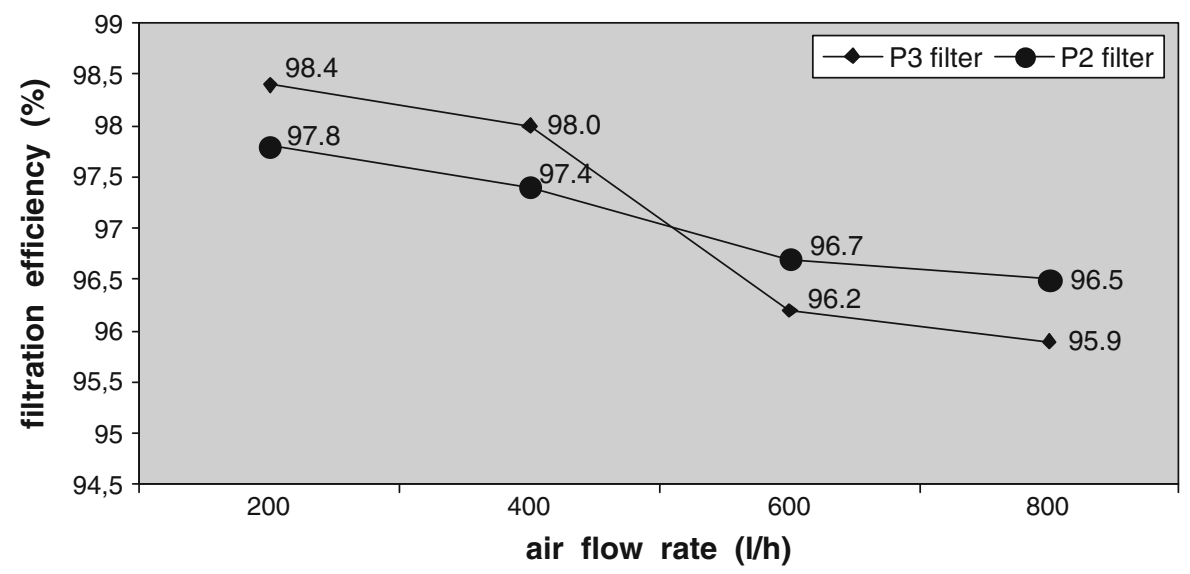

Fig. 2 Effect of air flow rate on P2 and P3 bio-filtration efficiency (M. luteus)

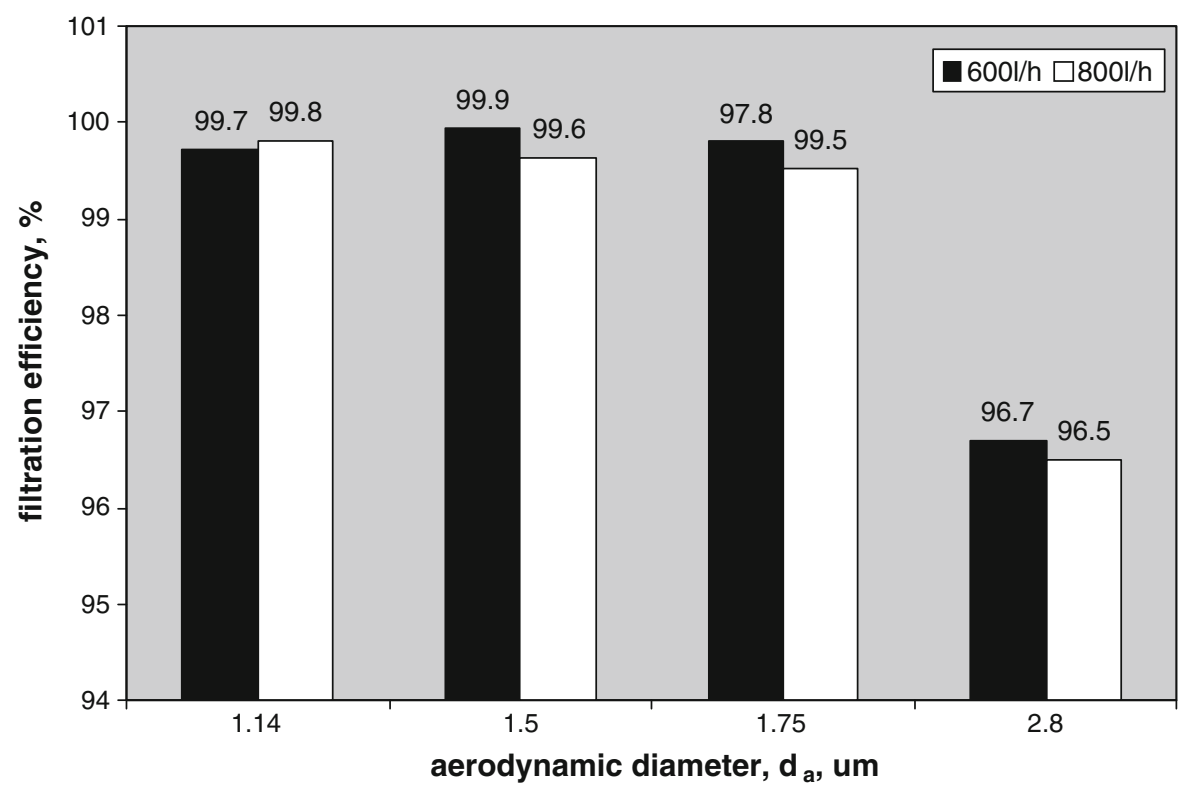

Fig. 3 Comparison of the filtration efficiency for bacterial cells of different aerodynamic diameter: $1.14 \mu \mathrm{m}-B$. subtilis, $1.5 \mu \mathrm{m}-P$. putida, $1.75 \mu \mathrm{m}-M$. varians and $2.8 \mu \mathrm{m}-M$. luteus) 
Moreover, the culture method used to estimate the number of bacteria might also influence the result of filtration efficiency. M. luteus cells' aggregates probably disintegrated during their impact on air filter, and then the number of the colony forming units on the solid medium raised. Jankowska et al. (2000) tested the air filters of medium and higher efficiency with fungal spores and mineral- $\mathrm{KCl}$ particles. In case of a medium efficiency filter, fungal spores were collected in 69 (Penicillium brevicompactum) and 73\% ( $P$. melinii) while $\mathrm{KCl}$ particles of the same size in 79 and $85 \%$, respectively. Additionally, filters collection efficiency increased with the aerodynamic size only in case of mineral particles. They explained such a difference as a consequence of spore clusters break-up and difference in particles surface structure.

Huang et al. (2008) compared air filters efficiency for aerosolized bacterial cells and bacterial and fungal spores and polystyrene latex particles (PSL) of the same particle aerodynamic diameter. They found that fungal spores of 2-3.5 and 3.5-5 $\mu \mathrm{m}$ were retained with the same efficiency as PSL particles of $3.0 \mu \mathrm{m}$, while bacterial cells and spores were arrested with higher efficiency than PSL spheres of corresponding size.

Wake et al. (1997) measured the penetration of bacterial cells, urea and sodium chloride particles in woven filter material from respirator filter cartridges, nuisance dust masks and surgical masks. They found out that the results obtained for the three groups of aerosols differed. In case of nuisance, dust masks penetration of bacterial cells was up to $100 \%$, while for non-biological particles, it reached $91 \%$. However, the results for bioaerosols generally corresponded to those for the monodisperse non-biological aerosols of the same particles size.

Nevertheless, application of particles of biological origin as a standard aerosol, or its component, creates some problems. One of them is bioaerosol susceptibility to changes in size. Gorny et al. (1999) observed that $d_{\mathrm{a}}$ of Micrococcus sp. changed in the range 2.1-3.3 $\mu \mathrm{m}$. Jung et al. (2010) noticed that E.coli cells increased after nebulization in a 1 -jet Collison nebulizer; their geometric size diameter changed from 0.779 to $0.907 \mu \mathrm{m}$ which was interpreted as a result of cells agglomeration.

Other problem is a procedure of bioaerosol preparation. Grinshpun et al. (1995) found out that bacterial cells washing, undertaken to reduce the residue present in suspension prior to atomization, caused significant decrease in cells size. They also noticed that nebulization is very stressful for bacteria. The problem of bacterial and also fungal cells susceptibility on stress was raised also by Whyte et al. (2007) and Yao and Mainelis (2006). Griffiths et al. (1996) listed the most important factors affecting microbial culturability. They are as follows: initial growth conditions, storage and contact time in liquid suspension before aerosolization, environmental conditions, aerosolization technique and collection mechanisms.

Another set of experiments dealt with the reemission of bacterial cells from filters into treated air. Two values of an air flow were tested: 600 and 800 1/h. Both of them were higher than the loading velocity. The bioaerosol concentration measured upstream reached $3.4 \times 10^{5} \mathrm{CFU} / \mathrm{m}^{3}$, and bacterial strains were in the following proportions: Micrococcus varians $(1.9 \times$ $\left.10^{5} \mathrm{CFU} / \mathrm{m}^{3}\right)$, Pseudomonas putida $\left(1.4 \times 10^{5} \mathrm{CFU} /\right.$ $\left.\mathrm{m}^{3}\right)$ and Bacillus subtilis $\left(1.3 \times 10^{4} \mathrm{CFU} / \mathrm{m}^{3}\right)$. The reemission rate at 600 and $800 \mathrm{l} / \mathrm{h}$ was similar for P. putida and B. subtilis (Tables 3, 4).

Flow rate 600 and $8001 / \mathrm{h}$ resulted in the highest remission values for $P$. putida: 0.63 and $0.61 \%$, respectively and the lowest for $M$. varians ( 0 and $0.35 \%)$. The percentage of emitted particles increased together with the increase in air velocity (from 600 to $800 \mathrm{l} / \mathrm{h}$ ) and was in the range of $0.39-0.63 \%$.

When the dynamics of reemission was concerned, the highest number of bacterial cells got into the air within first $5 \mathrm{~min}$; after that their number fluctuated (Table 5).

It is close to the result obtained by Jankowska et al. (2000). They also obtained similar rate of spores reemission, $0.4 \%$, and noticed that biological particles were emitted 100 times easier than mineral ones, when reemission velocity was higher than the loading one. They explained the difference between the results for bioaerosol and mineral aerosol as a consequence of aggregates formation and specific surface structure. According to Trunov et al. (2001), differences between bioaerosol and mineral aerosol retention may reach even $50 \%$, and particles surface characteristics is even more important than the aerodynamic particle diameter.

Bacterial and fungal cells and spores are unstable and highly differentiated but recommended DEHS particles seem not the ideal test aerosol either. 
Table 3 Results of bacterial reemission from filter P2, with the flow rate $600 \mathrm{l} / \mathrm{h}$

\begin{tabular}{lccccc}
\hline Bacteria & $\begin{array}{l}\text { Number of bacteria emitted } \\
\text { within } 20 \mathrm{~min}\left(\mathrm{CFU} / \mathrm{m}^{3}\right)\end{array}$ & $\begin{array}{l}\text { Standard } \\
\text { deviation }\end{array}$ & $\begin{array}{l}\text { Number of bacteria remaining } \\
\text { on the filter }\left(\mathrm{CFU} / 21.2 \mathrm{~cm}^{2}\right)\end{array}$ & $\begin{array}{l}\text { Standard } \\
\text { deviation }\end{array}$ & $\begin{array}{l}\text { Reemission } \\
\text { rate }(\%)\end{array}$ \\
\hline Micrococcus varians & 0 & 0 & 43,000 & 5,900 & 0 \\
Bacillus subtilis & 1,055 & 270 & 230,000 & 50,000 & 0.46 \\
Pseudomonas putida & 49 & 15 & 7,700 & 4,300 & 0.63 \\
Total & 1,104 & 127 & 280,000 & 110,000 & 0.39 \\
\hline
\end{tabular}

Table 4 Results of bacterial reemission from filter P2, with the flow rate $800 \mathrm{l} / \mathrm{h}$

\begin{tabular}{lccccc}
\hline Bacteria & $\begin{array}{l}\text { Number of bacteria emitted } \\
\text { within } 20 \mathrm{~min}\left(\mathrm{CFU} / \mathrm{m}^{3}\right)\end{array}$ & $\begin{array}{l}\text { Standard } \\
\text { deviation }\end{array}$ & $\begin{array}{l}\text { Number of bacteria remaining } \\
\text { on the filter }\left(\mathrm{CFU} / 21.2 \mathrm{~cm}^{2}\right)\end{array}$ & $\begin{array}{l}\text { Standard } \\
\text { deviation }\end{array}$ & $\begin{array}{l}\text { Reemission } \\
\text { rate }(\%)\end{array}$ \\
\hline Micrococcus varians & 63 & 7 & 18,000 & 4,500 & 0.35 \\
Bacillus subtilis & 268 & 68 & 50,000 & 1,100 & 0.53 \\
Pseudomonas putida & 27 & 7 & 4,400 & 310 & 0.61 \\
Total & 358 & 35 & 72,000 & 14,000 & 0.49 \\
\hline
\end{tabular}

Undoubtedly, they are stable (droplet size is stable for $4 \mathrm{~h}$ ), easy to generate in concentration and size range required and can be used as neutral aerosol. Additionally, spherical liquid particles are more accurately determined with optical particle sizer than irregular solid (test dust or salt) particles (Gustavsson 2003). The main disadvantage of DEHS application is that the particles are ideally regular unlike most of the airborne mineral or biological particles and as a liquid they do not rebound from filters but are firmly retained (ASHRAE 52.2 recommend $\mathrm{KCl}$ particles for such tests). For these reasons, DEHS particles should be used to test filters efficiency in mist aerosol, not solid particles filtration.

Standard deviation values for the number of bacteria were significant in case of both bacteria concentration in the air and their number on the filters, but the sample statistically analysed was very small.

\section{Conclusions}

The filters efficiency was studied experimentally using bioaerosols and non-biological aerosols. It was carried out to verify, if the conventional test aerosols and bioaerosols gave the same filters efficiency characteristics.
Also bacterial reemission from the filtering material was under investigation. The highest collection efficiency, $100 \%$, of P2 filter was noted for mineral dust particles, while efficiency of the same filter tested with mixed bioaerosol never reached such a high value and differed between the strains. In case of M. varians, P. putida and B. subtilis, the average efficiency of the filter was $99.7 \%$. Different behaviour was observed for the largest bio-particles-M. luteus $\left(d_{\mathrm{a}} 2.8 \mu \mathrm{m}\right)$; collection efficiency was $\sim 96 \%$, which is about $3 \%$ lower than for other bacterial strains and non-biological particles. It can be explained by the deaggregation of 8-cell packets during or after impaction or weak adhesion of spiny surface structure. Reemission of microorganisms from air filters was not significant and tended to increase with the increase in the air flow rate from 600 to $800 \mathrm{l} / \mathrm{h}$, i.e. $0.08-0.1 \mathrm{~m} / \mathrm{s}$. Since microorganisms (also pathogenic) are deposited in the air filters installed in the HVAC system, higher air flow velocity such as $30 \mathrm{~m} / \mathrm{s}$ must result in the distribution of microbes from filters into air ducts and finally, rooms. The most intense reemission was observed during the first $5 \mathrm{~min}$. after the air flow had begun. The reemission rate depends on the particle size and structure. It was noticed that for smooth particles, reemission decreased when $d_{\mathrm{a}}$ increased. In case of 
Table 5 Changes in bacterial reemission $(600 \mathrm{l} / \mathrm{h})$ within $25 \mathrm{~min}$

\begin{tabular}{|c|c|c|c|c|c|}
\hline $\begin{array}{l}\text { Sampling } \\
\text { time (min) }\end{array}$ & $\begin{array}{l}\text { Number of bacteria } \\
\text { emitted }\left(\mathrm{CFU} / \mathrm{m}^{3}\right)\end{array}$ & $\begin{array}{l}\text { Standard } \\
\text { deviation }\end{array}$ & $\begin{array}{l}\text { Number of bacteria remaining } \\
\text { on the filter }\left(\mathrm{CFU} / 21.2 \mathrm{~cm}^{2}\right)\end{array}$ & $\begin{array}{l}\text { Standard } \\
\text { deviation }\end{array}$ & $\begin{array}{l}\text { Reemission } \\
\text { rate }(\%)\end{array}$ \\
\hline \multirow[t]{4}{*}{$0-5$} & M. varians 0 & 0 & M. varians 43,000 & 13,000 & 0 \\
\hline & B. subtilis 582 & 190 & B. subtilis 230,000 & 54,000 & 0.25 \\
\hline & P. putida 46 & 7 & P. putida 7,700 & 2,400 & 0.59 \\
\hline & Sum 682 & 150 & Sum 280,000 & 130,000 & In general $0.22^{\mathrm{a}}$ \\
\hline \multirow[t]{4}{*}{$5-10$} & M. varians 0 & 0 & & & 0 \\
\hline & B. subtilis 56 & 10 & & & 0.02 \\
\hline & P. putida 0 & 0 & & & 0 \\
\hline & Sum 56 & 10 & & & In general $0.019^{\mathrm{a}}$ \\
\hline \multirow[t]{4}{*}{$10-15$} & M. varians 0 & 0 & & & 0 \\
\hline & B. subtilis 0 & 0 & & & 0 \\
\hline & P. putida 0 & 0 & & & 0 \\
\hline & Sum 0 & 0 & & & In general $0^{\mathrm{a}}$ \\
\hline \multirow[t]{4}{*}{$15-20$} & M. varians 0 & 0 & & & 0 \\
\hline & B. subtilis 381 & 76 & & & 0.17 \\
\hline & P. putida 18 & 2 & & & 0.23 \\
\hline & Sum 399 & 130 & & & In general $0.14^{\mathrm{a}}$ \\
\hline \multirow[t]{4}{*}{$20-25$} & M. varians 0 & 0 & & & 0 \\
\hline & B. subtilis 36 & 8 & & & 0.016 \\
\hline & P. putida 0 & 0 & & & 0 \\
\hline & Sum 36 & 8 & & & In general $0.013^{\mathrm{a}}$ \\
\hline
\end{tabular}

${ }^{a}$ With reference to the sum of the cells

spiny particles, their adhesion to the filter fibres was weak. The results of the study indicate the need for the development of a standard test aerosol that contains both mineral particles and biological ones, taking into account all specific properties of bio-particles or the results obtained for non-biological aerosols should be verified in test with bio-particles. Such two-step examination would guarantee reliable results of filters collection efficiency for all components of naturally occurring aerosols.

Open Access This article is distributed under the terms of the Creative Commons Attribution Noncommercial License which permits any noncommercial use, distribution, and reproduction in any medium, provided the original author(s) and source are credited.

\section{References}

Ahlen, C., Haugen, E. N., Frydenlund, F., Kristiansen, O., \& Lysne, H. N. (1999). Composting in ventilation filters? A possible key to altered thermotolerance in microbial flora of indoor air (Vol. 1, pp. 184-189). The 8th international conference on indoor air quality and climate, Edinburgh, Scotland 8-13 August. The International Academy of Indoor Air Quality and Climate (ISIAQ).

ASHRAE 52.2. (1999). Method of testing general ventilation air-cleaning devises used for removal efficiency by particle size. Atlanta, GA, USA: American National Standard.

Charkowska, A. (2000). Zanieczyszczenia instalacji klimatyzacyjnych i ich usuwanie. Problemy jakości powietrza wewnętrznego w Polsce' 99. Materiaty konferencyjne, 19-37.

EN 779. (2002). Particulate air filters for general ventilation. Determination of the filtration performance. Brussels, Belgium: The European Standard.

Gorny, R. L., Dutkiewicz, J., \& Krysinska-Traczyk, E. (1999). Size distribution of bacterial and fungal bioaerosols in indoor air. Annals of Agricultural and Environmental Medicine, 6, 105-113.

Griffiths, W. D., Stewart, I. W., Reading, A. R., \& Futter, S. J. (1996). Effect of aerosolisation, growth phase and residence time in spray collection fluids on the culturability of cells and spores. Journal of Aerosol Science, 27(5), 803-820.

Grinshpun, S. A., Willeke, K., Ulevicius, V., Qian, Y., \& Donnelly, J. (1995). Aerodynamic particle sizing of 
airborne bacteria. Journal of Aerosol Science, 26(Suppl. 1), 879-880.

Gustavsson, J. (2003). EN779:2002-New European test method for air filters. Filtration \& Separation, 3, 22-26.

Heikkinen, M. S. A., Hjelmroos-Koski, M. K., Habblom, M. M., Macher, J.M. (2005). Bioaerosols. In L. S. Ruzer \& N. S. Harley (Eds.), Aerosols handbook: Measurements, dosimetry and health effects (pp. 292-321). Boca Raton: CRC Press.

Huang, R., Agranovski, I., Pyankov, O., \& Grinshpun, S. (2008). Removal of viable bioaerosol particles with a low-efficiency HVAC filter enhanced by continuous emission of unipolar air ions. Indoor Air, 18, 106-112.

Jankowska, E., Reponen, T., Willeke, K., Grinshpun, S., \& Choi, K.-J. (2000). Collection of fungal spores on air filters and spore reentrainment from filters into air. Journal of Aerosol Science, 31(8), 969-978.

Jung, J. H., Lee, J. E., Hwang, G. B., Lee, B. U., Lee, S. B., Jung, J. S., et al. (2010). Electrospray-assisted ultraviolet aerodynamic particle sizer spectrometer for real-time characterization of bacterial particles. Analytical Chemistry, 82(2), 664-671.

Krzysztofik, B. (1992). Mikrobiologia powietrza. Wydawnictwa Politechniki Warszawskiej.

Maus, R., Goppelsroder, A., \& Umhauer, H. (2001). Survival of bacteria and mold spores in air filter media. Atmospheric Environment, 35, 105-133.

Martikainen, P. J., Asikainen, A., Nevalainen, A. m., Jantunen, M., Pasanen, P., \& Kalliokoski, P. (1990). Microbial growth on ventilation filter materials. Proceedings of the fifth international conference on indoor air quality and climate, Toronto (Vol. 3, pp. 203-206).

Martiny, H., Moritz, M., \& Ruden H. (1994). Deposit of bacteria and fungi in different materials of air conditioning systems. Proceedings of the international symposium on control, Yokohama (pp. 271-274).

PN-EN1822-1 (2010). High-efficiency air filters (EPA, HEPA, ULPA). Part 1: Classification, parameters examination, marking (in Polish).

Trunov, M., Trakumas, S., Willeke, K., Grinshpun, S. A., \& Reponen, T. (2001). Collection of bioaerosol particles by impaction: effect of fungal spore agglomeration and bounce. Aerosol Science and Technology, 34, 490-498.

Wake, D., Bowry, B., Crook, B., \& Brown, R. C. (1997). Performance of respirator filters and surgical masks against bacterial aerosols. Journal of Aerosol Science, 28(7), 1311-1329.

Wake, D., Redmayne, A. C., Thorpe, A., Gould, J. R., Brown, R. C., \& Crook, B. (1995). Sizing and filtration of microbiological aerosols. Journal of Aerosol Science, 26(Suppl. 1), S529-S530.

Whyte, W., Green, G., \& Albisu, A. (2007). Collection efficiency and design of microbial samplers. Journal of Aerosol Science, 38, 101-114.

Yao, M., \& Mainelis, G. (2006). Effect of physical and biological parameters on enumeration of bioaerosols by portable microbial impactors. Journal of Aerosol Science, 37, 1467-1483. 